\title{
Critical Role of Peripheral Vasoconstriction in Fatal Brain Hyperthermia Induced by MDMA (Ecstasy) under Conditions That Mimic Human Drug Use
}

\author{
Eugene A. Kiyatkin, Albert H. Kim, Ken T. Wakabayashi, Michael H. Baumann, and Yavin Shaham \\ Intramural Research Program, National Institute on Drug Abuse-National Institutes of Health, Baltimore, Maryland 21224
}

MDMA (Ecstasy) is an illicit drug used by young adults at hot, crowed "rave" parties, yet the data on potential health hazards of its abuse remain controversial. Here, we examined the effect of MDMA on temperature homeostasis in male rats under standard laboratory conditions and under conditions that simulate drug use in humans. We chronically implanted thermocouple microsensors in the nucleus accumbens (a brain reward area), temporal muscle, and facial skin to measure temperature continuously from freely moving rats. While focusing on brain hyperthermia, temperature monitoring from the two peripheral locations allowed us to evaluate the physiological mechanisms (i.e., intracerebral heat production and heat loss via skin surfaces) that underlie MDMA-induced brain temperature responses.

Our data confirm previous reports on high individual variability and relatively weak brain hyperthermic effects of MDMA under standard control conditions (quiet rest, $22-23^{\circ} \mathrm{C}$ ), but demonstrate dramatic enhancements of drug-induced brain hyperthermia during social interaction (exposure to male conspecific) and in warm environments $\left(29^{\circ} \mathrm{C}\right)$. Importantly, we identified peripheral vasoconstriction as a critical mechanism underlying the activity- and state-dependent potentiation of MDMA-induced brain hyperthermia. Through this mechanism, which prevents proper heat dissipation to the external environment, MDMA at a moderate nontoxic dose $(9 \mathrm{mg} / \mathrm{kg}$ or $\sim 1 / 5$ of $\mathrm{LD}_{50}$ in rats) can cause fatal hyperthermia under environmental conditions commonly encountered by humans. Our results demonstrate that doses of MDMA that are nontoxic under cool, quiet conditions can become highly dangerous under conditions that mimic recreational use of MDMA at rave parties or other hot, crowded venues.

Key words: acute intoxication; brain temperature; MDMA; peripheral vasoconstriction; social interaction; warm environment

\section{Introduction}

3,4-Methylenedioxymethamphetamine (MDMA; "Ecstasy," "Molly") is a psychoactive amphetamine derivative used for recreational purposes worldwide (United Nations World Drug Report, 2013). MDMA is a Schedule I controlled substance in the United States and under similar restrictions in most Western countries, but whether MDMA is harmful remains a contentious issue (Pentney, 2001; Check, 2004; Parrott, 2013). Initial studies in human and laboratory animals showed that MDMA exposure can induce life-threatening health complications, including fatal hyperthermia (Gordon et al., 1991; Ricaurte et al., 2000; Kalant, 2001). However, clinical evidence suggests that MDMA at low doses may be beneficial as a therapeutic adjunct in the treatment of post-traumatic stress disorder (PTSD) and other anxiety-related disorders (Doblin, 2002; Bouso et al., 2008; Mithoefer et al., 2013).

\footnotetext{
Received Feb. 5, 2014; revised March 31, 2014; accepted April 22, 2014.

Author contributions: E.A.K. and Y.S. designed research; E.A.K., A.H.K., and K.T.W. performed research; E.A.K., A.H.K., and K.T.W. analyzed data; E.A.K., M.H.B., and Y.S. wrote the paper.

This work was supported by the National Institute on Drug Abuse, Intramural Research Program. We thank Drs. David Epstein and Markus Heilig for helpful comments on this manuscript.

The authors declare no competing financial interests.

Correspondence should be addressed to Eugene A. Kiyatkin, 333 Cassell Drive, Baltimore, MD 21224. E-mail: ekiyatki@intra.nida.nih.gov.

DOI:10.1523/JNEUROSCI.0506-14.2014

Copyright $\odot 2014$ the authors $\quad 0270-6474 / 14 / 347754-09 \$ 15.00 / 0$
}

The magnitude of MDMA's effects on body temperature and other physiological measures is highly variable (Gordon et al., 1991; Carvalho et al., 2002; Mechan et al., 2002; Fantegrossi et al., 2003; Miller and O'Callaghan, 2003; Freedman et al., 2005). These studies also show that effects of MDMA vary across species, are dependent on dose and experimental conditions, and are strongly amplified at warm ambient temperatures. These findings are noteworthy, because MDMA is often used during rave parties characterized by hot, humid environments, where heat dissipation to the external environment is inefficient, and intense social interactions, which increase heat production. If these conditions are combined with MDMA, which by itself induces metabolic activation and enhanced heat production (Gordon et al., 1991; Brown and Kiyatkin, 2004) and also impairs the mechanisms of heat loss due to cutaneous vasoconstriction (Gordon et al., 1991; Pedersen and Blessing, 2001), the hyperthermic effects of MDMA could be dramatically enhanced.

In the present study, we examined the effect of MDMA on brain temperature homeostasis in awake, freely moving rats under standard laboratory conditions and under conditions that more closely simulate human drug use: social interaction and a warm environment. While in a previous study (Brown and Kiyatkin, 2004) we showed that brain hyperthermic effects of MDMA are augmented under these conditions, here we explored the physiological mechanisms underlying this potentiation, spe- 
cifically the contribution of intrabrain heat production, and impairment of heat loss due to peripheral vasoconstriction. For this purpose, in addition to monitoring brain temperature, we also simultaneously recorded temperatures from the temporal muscle and facial skin. The temperature difference between brain and temporal muscle, which both receive arterial blood supply from the carotid artery, allowed us to evaluate the source of heat production, and thus isolate MDMA's effects on brain metabolism. The temperature difference between skin and temporal muscle is a reliable index of peripheral vascular tone (i.e., vasoconstriction/ vasodilation), a critical factor affecting heat accumulation in the brain (Kiyatkin, 2010). We first used our three-point thermorecording (brain, temporal muscle, and facial skin) along with monitoring rat locomotor activity to examine the effects of MDMA under standard laboratory conditions (quiet rest, $\left.22-23^{\circ} \mathrm{C}\right)$. We then examined the modulation of MDMA's effects during social interaction and at moderately warm ambient temperatures $\left(29^{\circ} \mathrm{C}\right)$. We chose the nucleus accumbens (NAc), a deep brain structure involved in sensorimotor integration and psychostimulant reward (Mogenson et al., 1980; Wise, 1989; Badiani et al., 2011) as the location of our brain thermorecordings.

\section{Materials and Methods}

Subjects, surgery, and thermocouple sensors. We used 12 Long-Evans rats (Charles River Laboratories), 3-4 months in age and $450 \pm 30 \mathrm{~g}$ in weight, which were housed individually ( $12 \mathrm{~h}$ light cycle beginning at 7:00) with ad libitum access to food and water. Protocols were performed in compliance with the Guide for the Care and Use of Laboratory Animals (National Institutes of Health, Publication 865-23) and were approved by the Animal Care and Use Committee, NIDA IRP.

Each rat underwent the same procedure of three-point thermocouple electrode implantation described in detail previously (Kiyatkin and Brown, 2005). We implanted under general anesthesia (Equithesin, 0.33 $\mathrm{ml} / 100 \mathrm{~g}$, i.p.; dose of sodium pentobarbital $32.5 \mathrm{mg} / \mathrm{kg}$ and chloral hydrate $145 \mathrm{mg} / \mathrm{kg}$ ) miniature copper-constantan thermocouple probes (125 $\mu \mathrm{m}$ in diameter) in NAc shell $(\mathrm{AP}=1.2 \mathrm{~mm} ; \mathrm{L}=0.9 \mathrm{~mm}$; $\mathrm{DV}=$ 7.2-7.4 mm), deep temporal muscle (musculus temporalis) and subcutaneously, along the nasal ridge with the tip $\sim 15 \mathrm{~mm}$ anterior to bregma. We secured the probes with dental cement to three stainless steel screws threaded into the skull. We allowed the rats $5 \mathrm{~d}$ to recover from surgery before the experiments began.

We chose the NAc shell, a ventrally located brain structure involved in sensorimotor integration and psychostimulant reward (Mogenson et al., 1980; Wise, 1989; Badiani et al., 2011), as a representative brain area. Recordings from this brain area were used in our previous physiological and pharmacological studies (Kiyatkin, 2013), thus allowing betweenstudy comparisons of brain temperature dynamics. The two other recording sites served to examine the mechanisms underlying brain temperature responses. Since the temporal muscle and the brain receive arterial blood from the same common carotid artery and thus are equally exposed to blood-delivered heat from the body, NAc-Muscle temperature differences show the source of heat production, providing a measure of drug-induced metabolic brain activation (Kiyatkin, 2010). Skin temperature is determined by the state of peripheral vessels, but it also depends on temperature of arterial blood inflow. Therefore, Skin-Muscle temperature differences serve as an accurate measure of peripheral vascular tone, another important determinant of brain temperature changes (Kiyatkin, 2010). Specifically, increases in Skin-Muscle differential indicate enhanced heat loss due to vasodilation whereas decreases indicate diminished heat loss due to vasoconstriction. While cutaneous vasoconstriction per se can also be assessed by using Doppler signal for monitoring fluctuations in blood flow (Pedersen and Blessing, 2001; Blessing et al., 2003; Rusyniak et al., 2008), this technique is difficult to implement in freely moving rats, especially when combined with other physiological measurements. Moreover, in rats this technique can only be used in the tail, where blood flow and local temperatures fluctuate widely at ambient temperatures around the rat's thermoneutral zone (Romanovsky et al.,
2002). Moreover, monitoring of skin temperature alone without excluding the influence of arterial blood temperature can be misleading when evaluating relatively long-term, tonic effects of drugs on heat loss (see Results).

Experimental protocol. All recordings took place during the light phase of the rat's cycle in a light- and sound-attenuated chamber under a dim white light. Each morning, we brought the rats from their housing facility, placed them in the chamber, and connected them to the recording instrument (Thermes-16; Physitemp Instruments) via individual sockets attached to a common cord and an electric swivel commutator. During each recording session, the rats habituated to the experimental environment for at least $2 \mathrm{~h}$. We exposed each rat to two habituation sessions $(\sim 6$ $h$ each) before surgeries and one habituation session $(6 \mathrm{~h})$ thereafter, which preceded MDMA or saline injections. We recorded temperatures continuously and collected the data at 10 -s intervals. We maintained room temperature at either $22.5 \pm 0.5^{\circ} \mathrm{C}$ ("standard laboratory conditions") or $29.0 \pm 0.5^{\circ} \mathrm{C}$ ("warm environmental conditions"). We also recorded the ambient temperature during the sessions by an additional thermosensor mounted inside the test cage. We also measured locomotor activity using photobeams as previously described (Smirnov and Kiyatkin, 2008).

We exposed all rats to the same two-week experimental protocol. During the first week, we determined the dose-response effects of MDMA. The drug was dissolved in $0.3 \mathrm{ml}$ of saline and administered subcutaneously at a dose of 1,3 , and $9 \mathrm{mg} / \mathrm{kg}$ during three sequential daily sessions. Although humans typically self-administer MDMA via the oral route, we could not use this route in the present study because of the significant stress associated with the oral administration procedure in rats. We chose to administer the drug via the subcutaneous route because in rats it produces a much slower time to maximal MDMA concentration $\left(T_{\max }\right)$ than the intraperitoneal route (Baumann et al., 2009). Moreover, the relationships between circulating MDMA and its major metabolites, 3,4dihydroxymethamphetamine and 4-hydroxy-3-methoxymethamphetamine, after subcutaneous administration in rats closely approximate those of oral MDMA dosing in humans (de la Torre et al., 2000; Kolbrich et al., 2008; Baumann et al., 2009; Concheiro et al., 2014). Since the subcutaneous injection procedure induces some degree of stress, we examined the effects of subcutaneous saline injections $(0.3 \mathrm{ml})$ in two sessions, one preceding and one following the MDMA sessions.

During a second week of testing, the rats underwent four experimental sessions. During the first two sessions, we examined the effects of saline and MDMA $(9 \mathrm{mg} / \mathrm{kg})$ during social interaction. We placed a novel, drug-naive conspecific male in the experimental rat's cage $10 \mathrm{~min}$ before and removed the intruder rat $50 \mathrm{~min}$ after the drug/saline injection. During this time period, we allowed the two rats to interact freely with each other.

During the next two sessions, we examined the effects of saline and MDMA $(9 \mathrm{mg} / \mathrm{kg})$ at warm ambient temperatures $\left(29^{\circ} \mathrm{C}\right)$. While this temperature is $7^{\circ} \mathrm{C}$ higher than standard housing conditions $\left(22-23^{\circ} \mathrm{C}\right)$, it corresponds to the thermoneutral zone in rats, when endogenous heat production is minimal and balanced with heat loss (Romanovsky et al., 2002). We only used one drug dose $(9 \mathrm{mg} / \mathrm{kg})$ in the social interaction and warm temperature conditions because this dose is regarded as a safe dose in studies of MDMA-induced toxicity, where the $\mathrm{LD}_{50}$ is $\sim 50 \mathrm{mg} / \mathrm{kg}$ (Davis et al., 1987). The $9 \mathrm{mg} / \mathrm{kg}$ dose, but not the lower doses ( 1 and 3 $\mathrm{mg} / \mathrm{kg}$ ), had consistent effects on brain temperature and locomotion (see Results), which allowed us to assess the potentiation effect of MDMA by social interaction and warm ambient temperature against baseline drug effects in control conditions (quiet rest, $22-23^{\circ} \mathrm{C}$ )

In all experiments, we injected MDMA or saline when rats were in quiet resting, sleep-like conditions when all temperature measures had stabilized at low basal levels. We continued the recordings for at least $5 \mathrm{~h}$ after MDMA or saline injections.

Histology. We determined the location of brain thermocouple sensors from cryostat-cut, $45 \mu \mathrm{m}$ slices mounted on glass slides. All rats included in this dataset had sensors located in the NAc shell according to the Paxinos and Watson (2005) atlas.

Data analysis. We present MDMA-induced temperature changes in four ways: as absolute changes in each recording location, as relative 
MDMA $1 \mathrm{mg} / \mathrm{kg}$

A

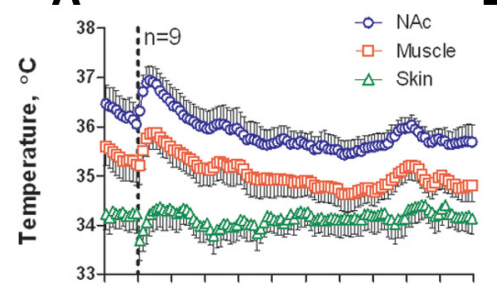

$\because$ E MDMA $1 \mathrm{mg} / \mathrm{kg}$-Saline
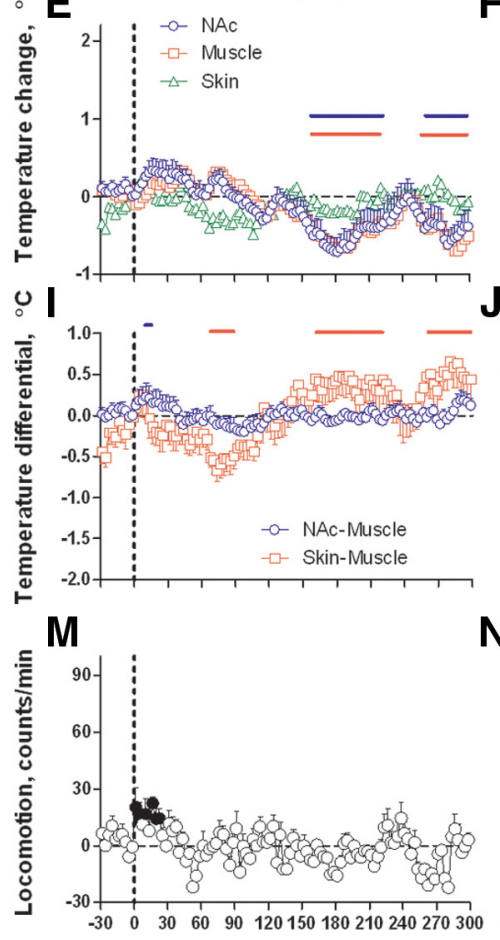

Time, $\min$
MDMA $3 \mathrm{mg} / \mathrm{kg}$

B

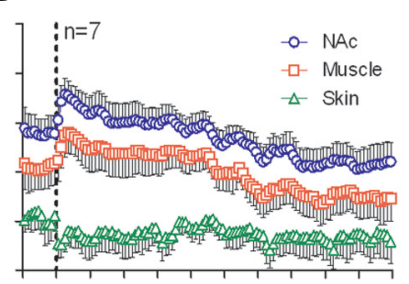

$F$
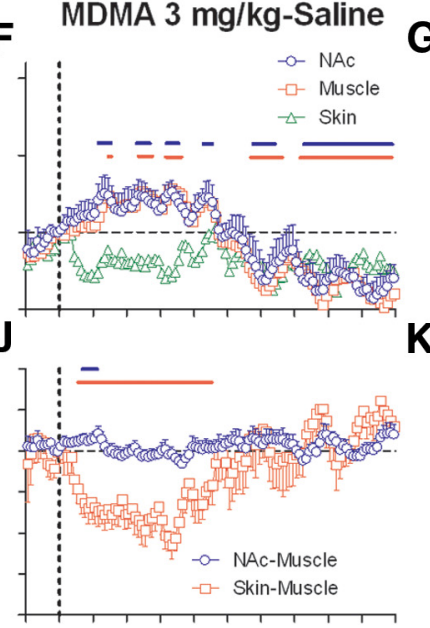

$\mathbf{N}$

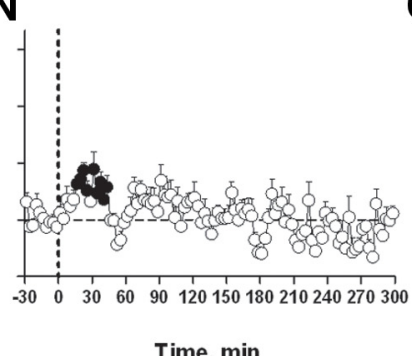

MDMA $9 \mathrm{mg} / \mathrm{kg}$

C

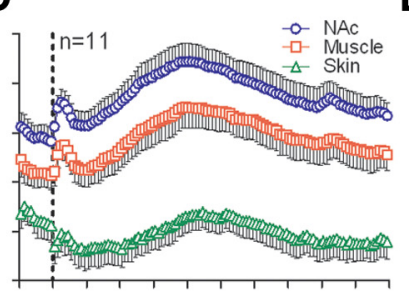

MDMA $9 \mathrm{mg} / \mathrm{kg}$-Saline
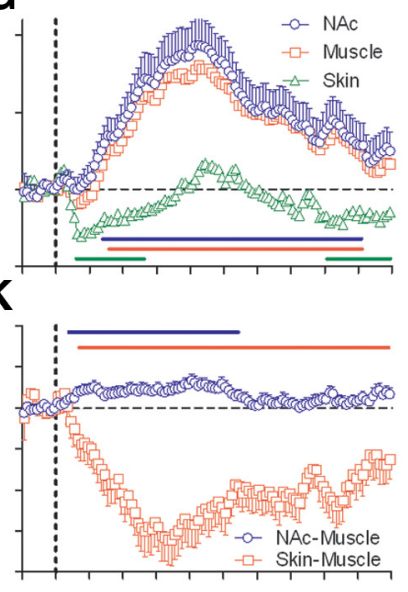

0

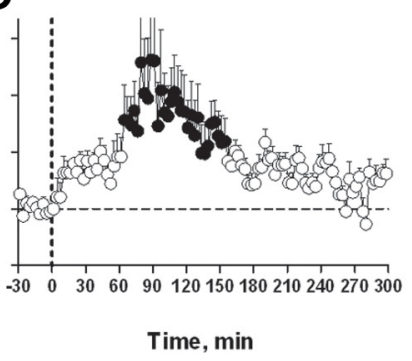

Saline

D
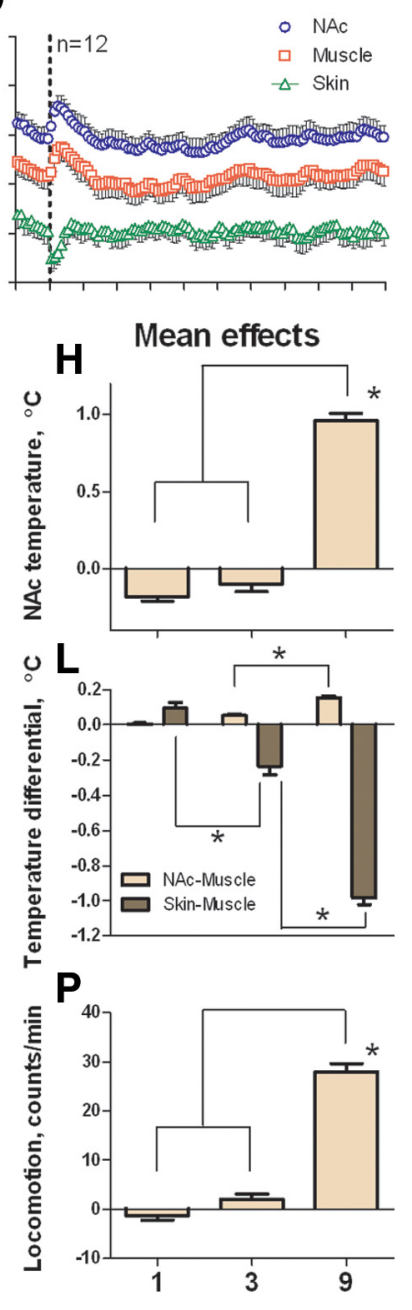

MDMA dose $(\mathrm{mg} / \mathrm{kg})$

Figure 1. Modest temperature and motor-activating effects of MDMA under quiet resting conditions at standard ambient temperatures $\left(22-23^{\circ} \mathrm{C}\right) . A-D, M e a n( \pm S E M)$ changes in NAc, muscle, and skin temperatures induced by injections of saline and MDMA (vertical hatched line). $n=$ number of rats per group. Mean ( \pm SEM) MDMA-induced changes in relative temperatures $(\boldsymbol{E}-\boldsymbol{G})$, temperature differentials $(\boldsymbol{I}-\boldsymbol{K})$, and locomotion $(\boldsymbol{M}-\mathbf{0})$. Values significantly different from baseline $(p<0.05)$ are shown as horizontal lines of respective color or as filled symbols $(\boldsymbol{M}-\mathbf{0})$. $\boldsymbol{H}, \boldsymbol{L}, \boldsymbol{P}$, Mean values of drug effects on individual parameters for $5 \mathrm{~h}$ post injection (area under curve/time unit). Asterisks show significant between-dose differences ( ${ }^{*} p<0.05$ ).

changes, as NAc-Muscle and Skin-Muscle temperature difference (a difference between relative temperature changes across the corresponding locations), and as a difference from the saline control condition. The first two parameters show the pattern and time course of temperature changes in each recording location, and we use the NAc-Muscle and Skin-Muscle temperature differences to determine the source of the brain temperature response and the strength of stimulus- or druginduced vasoconstriction, respectively (Kiyatkin, 2010). We use the last measure (MDMA - saline) to exclude the influence of the injection procedure from the total temperature response and reveal "pure" drug effects. We analyzed the temperature responses for each drug dose, using one-way ANOVA (dose) with repeated measures (time); we follow up on significant ANOVA results with Fisher's PLSD post hoc tests. We also performed Student's $t$ tests for between-dose and between-condition comparisons after calculating mean effects of MDMA on individual parameters as area under the curve over time.

\section{Results}

MDMA induces modest temperature effects under quiet resting conditions at standard room temperature $\left(22-23^{\circ} \mathrm{C}\right)$ Injections of different doses of MDMA rapidly increased NAc and muscle temperatures and rapidly decreased skin temperature
(Fig. 1A-C). These immediate (20-30 min) effects were mimicked by saline injections (Fig. $1 D$ ), suggesting that they are induced by the injection procedure rather than MDMA. In contrast, the subsequent delayed temperature changes were dependent on MDMA dose. At the lowest dose (1 mg/kg), temperature responses in all locations were barely distinguishable from those induced by saline. At the $3 \mathrm{mg} / \mathrm{kg}$ dose, the increases in NAc and muscle temperatures were slightly stronger and the skin temperature decrease was more prolonged. All these changes were greatly amplified after injections of MDMA at the $9 \mathrm{mg} / \mathrm{kg}$ dose. The mean effect of MDMA on NAc temperature was negative or close to zero at 1 and $3 \mathrm{mg} / \mathrm{kg}$, but became positive and significantly larger at $9 \mathrm{mg} / \mathrm{kg}\left(\right.$ Fig. $1 H ; t_{(19)}=19.6, p<0.01$ for $9 \mathrm{mg} / \mathrm{kg}$ vs $1 \mathrm{mg} / \mathrm{kg}$; and $t_{(18)}=14.9, p<0.01$ for $9 \mathrm{mg} / \mathrm{kg}$ vs $3 \mathrm{mg} / \mathrm{kg}$ ).

To determine a pure effect of MDMA on the different temperature measures, we subtracted the effects of saline from MDMA for each drug dose (Fig. $1 E-G, I-K, M-O$ ). Using this approach, MDMA at the lowest dose induced a weak, but significant biphasic effect on NAc and muscle temperatures $\left(F_{(8,791)}=5.6\right.$ and 6.0; $p<0.001$ ), with no effect on skin temperature (Fig. 1E). Post hoc 
analysis showed that the initial increase in NAc and muscle temperatures was not significant but both parameters significantly decreased from $\sim 180$ to 300 min post injection. The middle dose of MDMA (3 mg/kg) induced a similar, but stronger biphasic fluctuation of NAc and muscle temperatures $\left(F_{(6,692)}=12.0\right.$ and $11.0 ; p<0.001)$, without significantly affecting skin temperatures (Fig. $1 F)$. The high MDMA dose $(9 \mathrm{mg} / \mathrm{kg})$ monotonically increased brain and muscle temperature by $\sim 2^{\circ} \mathrm{C}$ while skin temperature showed a smaller triphasic fluctuation $\left(F_{(10,1088)}=13.9\right.$, 14.23 , and 6.8, respectively; $p<0.001$ ).

Brain temperature is primarily determined by two variables: intrabrain heat production and heat inflow or loss to the rest of the body, and then to the external environment. To exclude this latter influence from the periphery and identify the critical component related to metabolic brain activation and intrabrain heat production, we calculated NAc-Muscle temperature differentials, which show brain temperature changes relative to changes in temporal muscle temperature (Kiyatkin, 2010, 2013). Since both the brain and temporal muscle receive the same arterial blood inflow and thus are equally exposed to blood-delivered heat from the body, elevations of NAc-Muscle differentials indicate increased intracerebral heat production due to metabolic brain activation. Using this approach, we found that MDMA at 1 and $3 \mathrm{mg} / \mathrm{kg}$ doses increases the NAc-Muscle differential weakly and transiently; in contrast, the effect was much larger and more prolonged at the $9 \mathrm{mg} / \mathrm{kg}$ dose $\left(\right.$ Fig. $1 I-K ; F_{(8,791)}=1.9, F_{(6.692)}=$ 2.4 , and $F_{(10,1088)}=6.1$, respectively; $\left.p<0.01\right)$. This change was significantly greater than changes induced by the drug at the two lower doses (Fig. $1 L ; t_{(19)}=11.0, p<0.01$ for $9 \mathrm{mg} / \mathrm{kg}$ vs $1 \mathrm{mg} / \mathrm{kg}$, and $t_{(18)}=7.4, p<0.01$ for $9 \mathrm{mg} / \mathrm{kg}$ vs $3 \mathrm{mg} / \mathrm{kg}$ ).

We also calculated MDMA-induced changes in Skin-Muscle temperature differentials, a measure of peripheral vascular tone (Kiyatkin, 2010). This parameter was significantly affected by MDMA at each dose $\left(F_{(8,791)}=5.6, F_{(6.692)}=9.7\right.$, and $F_{(10,1088)}=$ 24.0 , respectively; $p<0.001)$, but vasoconstriction was weak and transient with subsequent vasodilation at the $1 \mathrm{mg} / \mathrm{kg}$ dose, stronger and more prolonged at $3 \mathrm{mg} / \mathrm{kg}$, and robust and prolonged at $9 \mathrm{mg} / \mathrm{kg}$ (Fig. $1 I-K$ ). Mean changes in this parameter were significantly different between each dose (Fig. $1 L ; 9 \mathrm{mg} / \mathrm{kg}$ vs $1 \mathrm{mg} / \mathrm{kg}, t_{(19)}=20.7,9 \mathrm{mg} / \mathrm{kg}$ vs $3 \mathrm{mg} / \mathrm{kg}, t_{(18)}=7.4,3 \mathrm{vs} 1 \mathrm{mg} / \mathrm{kg}$, $\left.t_{(15)}=5.4 ; p<0.01\right)$.

MDMA at each dose significantly affected locomotion $\left(F_{(8,791)}\right.$ $=4.1, F_{(6.692)}=3.8$, and $F_{(10,1088)}=3.0$, respectively; $\left.p<0.01\right)$, but true motor activation was found only with the high drug dose (Fig. 1M-O). The mean change (drug - saline) in locomotion was close to zero at 1 and $3 \mathrm{mg} / \mathrm{kg}$ MDMA doses, but became much larger at the $9 \mathrm{mg} / \mathrm{kg}$ (Fig. $1 P ; t_{(19)}=14.6$ for $9 \mathrm{mg} / \mathrm{kg}$ vs 1 $\mathrm{mg} / \mathrm{kg}$ and $t_{(18)}=12.7$ for $9 \mathrm{mg} / \mathrm{kg}$ vs $\left.3 \mathrm{mg} / \mathrm{kg} ; p<0.01\right)$.

\section{Social interaction strongly potentiates the hyperthermic, vasoconstrictive, and motor-activating effects of MDMA} Consistent with our previous work (Brown and Kiyatkin, 2004), the introduction of a male rat into the chamber occupied by the experimental rat undergoing recording induced locomotor activation; a rapid, strong rise in NAc and muscle temperatures $\left(\sim 1.5^{\circ} \mathrm{C}\right)$; and a brief decrease in skin temperature that was rapidly transformed into a more tonic, rebound-like increase (Fig. $2 A, B, D ; F_{(6.692)}=34.0,27.0$, and 3.4, respectively; $\left.p<0.01\right)$. While the changes in NAc and muscle temperatures were generally parallel, the rise was stronger and more rapid in the brain, resulting in a significant increase in NAc-Muscle differentials $\left(F_{(6.692)}=2.1, p<0.01\right)$, indicating metabolic brain activation (Fig. 2C). Social interaction was also accompanied by a strong

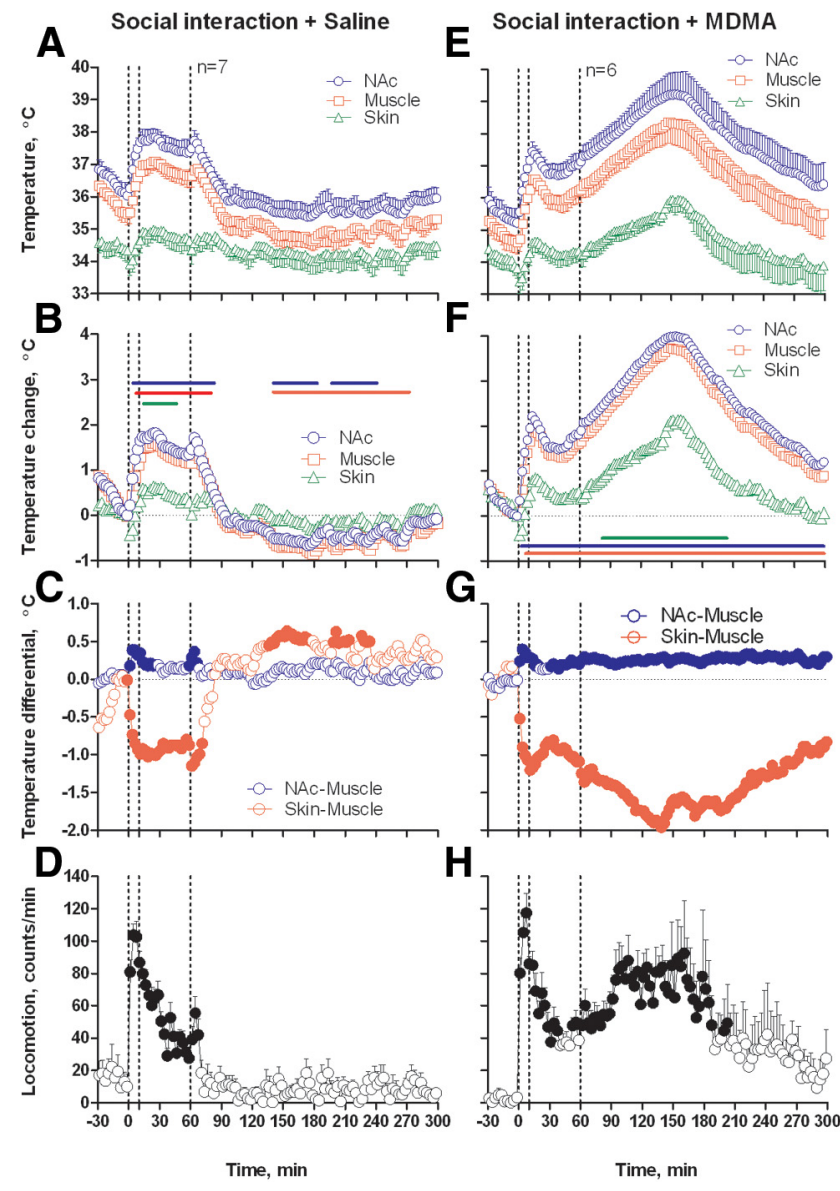

Figure 2. Potentiation of MDMA effects on temperature and locomotion during social interaction (I). Left, Shows changes in absolute $(\boldsymbol{A})$ and relative $(\boldsymbol{B})$ temperatures, temperature differentials $(\boldsymbol{C})$, and locomotion $(\boldsymbol{D})$ during social interaction (onset and offset are shown as vertical hatched lines at 0 and $60 \mathrm{~min}$ ). Saline was injected at $10 \mathrm{~min}$ after the start of interaction (second hatched line at $10 \mathrm{~min}$ ). $\boldsymbol{E}-\boldsymbol{H}$, Right, Shows changes in the same parameter when MDMA ( $9 \mathrm{mg} / \mathrm{kg}$ ) was injected at 10 min after the start of social interaction. Similar to Figure 1 , individual values are significantly different from baseline (at least $p<0.05$; Fisher post hoc tests after detecting a significant main effect of time with one-way repeated measures ANOVA) are shown by the horizontal lines of respective colors or as filled symbols $(\boldsymbol{D}, \boldsymbol{H})$.

decrease in Skin-Muscle temperature differentials $\left(\sim 1^{\circ} \mathrm{C} ; F_{(6.692)}=\right.$ 13.0, $p<0.001)$, indicating stimulus-induced cutaneous vasoconstriction. While NAc-Muscle differentials rapidly returned to baseline after the end of the social interaction period, Skin-Muscle differentials increased above baseline at this time, suggesting a rebound vasodilation. All these physiological parameters and locomotion showed consistent changes at the start and end of the social interaction. A saline injection during social interaction $(+10 \mathrm{~min}$ after its onset; Fig. 2, second vertical lines) had no effect on the parameters above.

When rats were injected with MDMA $(9 \mathrm{mg} / \mathrm{kg})$ at the tenth minute after the start of social interaction, brain and muscle temperatures began to increase slowly, peaking at $\sim 150$ min post injection at mean values $\sim 4^{\circ} \mathrm{C}$ higher ( or $39.2^{\circ} \mathrm{C}$ ) than baseline values (Fig. $2 E, F ; F_{(5,593)}=7.5$ and $7.1, p<0.001$ ). This temperature change was much greater than that induced by MDMA under quiet resting conditions $\left(+1.8^{\circ} \mathrm{C}\right.$; Fig. 1$)$, but the increase in NAc-Muscle differential was equally strong and prolonged (Fig. 2G). While skin temperature after the initial decrease also slowly increased due to the inflow of warmer arterial blood, the Skin-Muscle differential dropped significantly $\left(\sim 2^{\circ} \mathrm{C} ; F_{(5,593)}=\right.$ $3.5, p<0.01)$, indicating powerful and prolonged vasoconstric- 

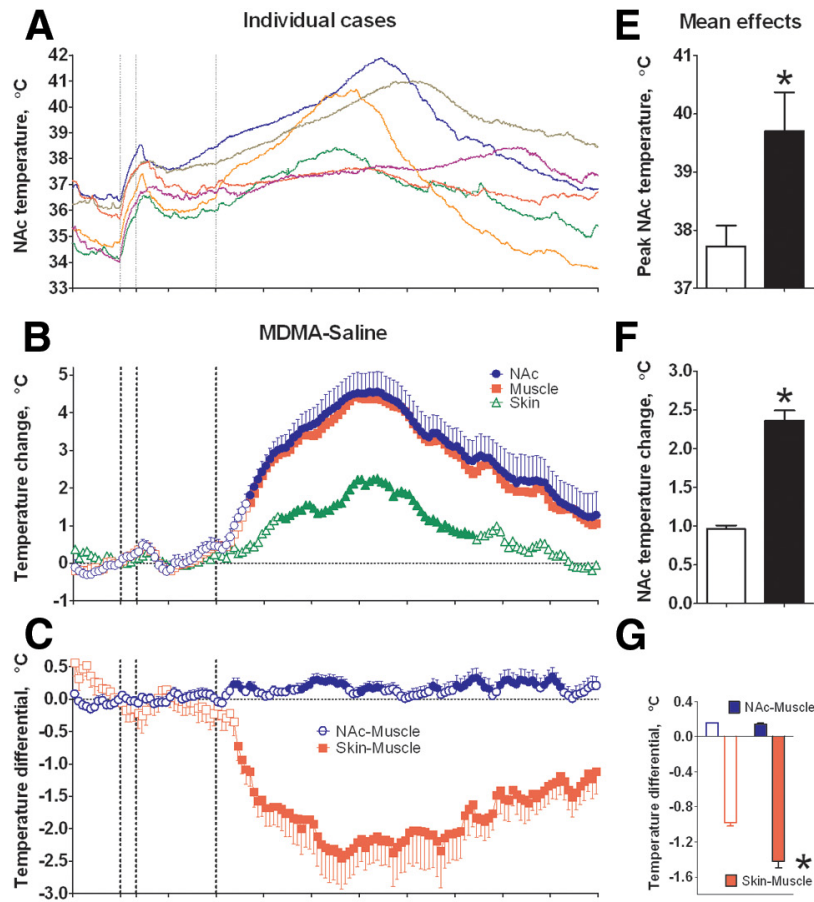

G
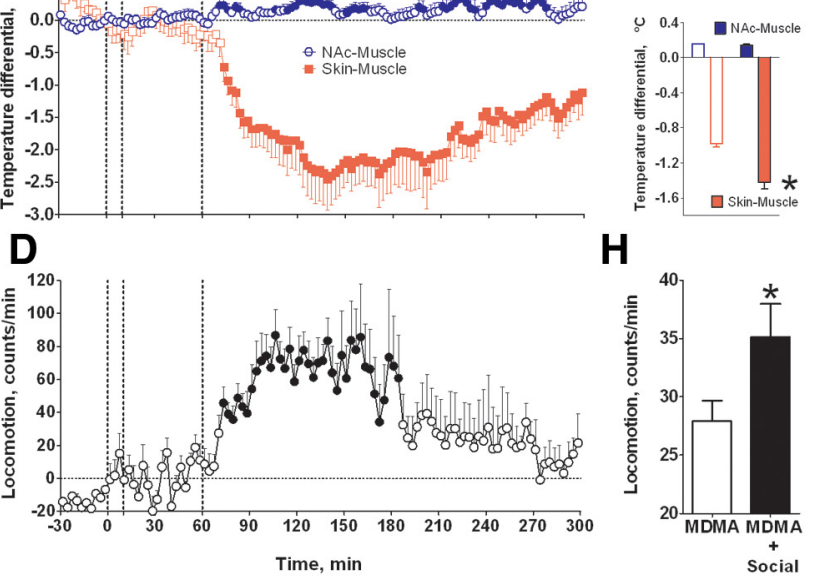

H

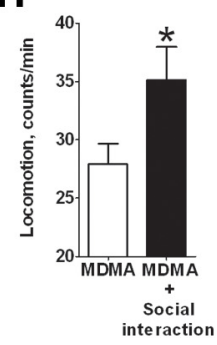

Figure 3. Potentiation of MDMA effects on temperature and locomotion during social interaction (II). $\boldsymbol{A}$, Individual changes in brain temperatures following MDMA exposure $(9 \mathrm{mg} / \mathrm{kg}$ ) during social interaction. Mean ( \pm SEM) MDMA-induced changes in NAc, muscle, and skin temperatures (B); NAc-Muscle and Skin-Muscle temperature differentials ( $\boldsymbol{C}$; and locomotion (D) during social interaction (MDMA-Saline). Filled symbols show values significantly different from baseline. $\boldsymbol{E}-\boldsymbol{H}$, Differences in MDMA effects under quiet resting conditions and during social interaction. Asterisks show significant between-group (saline vs MDMA) differences $\left({ }^{*} p<0.05\right)$.

tion, which was still evident at the end of the $5 \mathrm{~h}$ measurement duration. MDMA injections during social interaction also induced the second, drug-related peak in locomotion (Fig. $2 F$ ). Finally, while we observed no adverse effects of $9 \mathrm{mg} / \mathrm{kg}$ MDMA under quiet resting conditions, one of the six rats exposed to this MDMA dose during social interaction died within $18 \mathrm{~h}$ post injection.

Robust state-dependent potentiation of the hyperthermic effects of MDMA is shown in Figure 3, which shows the pure effects of this drug $(9 \mathrm{mg} / \mathrm{kg})$ injected during social interaction (MDMA - saline; Fig. 3B-D) and the between-state differences (social interaction vs single-housed condition) in MDMA effects (Fig. $3 E-H$ ). Similar to quiet resting conditions, MDMA injected during social interaction induced greater increases in NAc temperature, with peak values varying from 37.9 to $41.9^{\circ} \mathrm{C}$ (Fig. $3 \mathrm{~A}$ ); mean values were substantially larger for both the response peaks (Fig. $3 E ; 39.7 \pm 0.67$ vs $37.7 \pm 0.36^{\circ} \mathrm{C} ; t_{(16)}=2.6, p<0.05$ ) and mean temperature elevation (Fig. $3 F ; t_{(16)}=9.2 ; p<0.01$ ). By this parameter, the effect of MDMA during social interaction was more than doubled. While MDMA also increased the NAc-
Muscle differential (Fig. 3C), its mean change was similar to that seen with the drug injected in quiet resting conditions (Fig. $3 C, G$; $\left.t_{(16)}=0.8\right)$, suggesting a similar effect on metabolic brain activation in both conditions. In contrast, MDMA-induced decrease in Skin-Muscle differential in the social interaction condition was robust and very prolonged (Fig. $3 C$ ), greatly exceeding that seen under quiet resting conditions (Fig. $3 G ;-1.42 \pm 0.07^{\circ} \mathrm{C}$ vs $\left.-0.98 \pm 0.04^{\circ} \mathrm{C} ; t_{(16)}=5.5, p<0.01\right)$. MDMA-induced locomotor activation during social interaction was also significantly larger and more prolonged than that seen during quiet resting conditions (compare Figs. $1 O, 2 H ; t_{(16)}=2.2, p<0.05,3 D$ ).

\section{MDMA induces fatal hyperthermia in a moderately warm environment}

Consistent with previous studies (Kiyatkin and Brown, 2004), rats exposed to a warm ambient temperature within their thermoneutrality zone $\left(29^{\circ} \mathrm{C}\right)$ maintained stable but slightly higher internal temperatures (mean: $36.7 \pm 0.2,36.2 \pm 0.2$, and $35.2 \pm$ $0.4^{\circ} \mathrm{C}$ for NAc, muscle, and skin, respectively) than rats housed under standard laboratory conditions at $22-23^{\circ} \mathrm{C}$ (mean: $35.9 \pm$ $0.2,35.2 \pm 0.3$, and $34.0 \pm 0.26^{\circ} \mathrm{C}$, respectively). The difference was minimal for the brain $\left(\Delta=0.76^{\circ} \mathrm{C}\right)$ and maximal for skin $\left(\Delta=1.17^{\circ} \mathrm{C}\right)$, suggesting weak tonic vasodilation as a way to promote dissipation of metabolic heat into the warmer environment. Saline injections under these conditions induced weak, transient injection-related temperature responses similar to that seen with saline injection at standard room temperature, but did not significantly change any temperature parameter or locomotion (Fig. 4E-H). However, when rats were injected with MDMA $(9 \mathrm{mg} / \mathrm{kg})$, all of them showed gradually rising temperatures leading to fatal hyperthermia $\left(>41^{\circ} \mathrm{C}\right)$ and lethality within $6 \mathrm{~h}$ post injection (Fig. 4A). Peak values of NAc temperatures after MDMA administration ranged from 41.4 to $43.8^{\circ} \mathrm{C}$, and their means were $>4^{\circ} \mathrm{C}$ larger than in the control condition (Fig. $4 E$; $42.2 \pm 0.4^{\circ} \mathrm{C}$ vs $\left.37.7 \pm 0.4^{\circ} \mathrm{C} ; t_{(16)}=8.5, p<0.01\right)$. Despite robust brain temperature elevation in each rat, the latency, rate of increase, and time of death varied substantially (from $85 \mathrm{~min}$ to $330 \mathrm{~min}$ ) among individual rats (Fig. $4 A$ ).

Figure $4 B-D$ shows mean changes in temperatures and locomotion for the first 83 min after MDMA administration, when all rats were still alive. In this case, all parameters changed significantly $\left(F_{(5.593)}=28.0,22.0,6.1\right.$, and 4.5 for NAc, muscle, and skin temperatures as well as locomotion; $p<0.001)$. NAc and muscle temperatures began to increase rapidly, exceeding $41^{\circ} \mathrm{C}$ ( or $>4^{\circ} \mathrm{C}$ above the pre-injection baseline). During this time interval, this increase greatly exceeded that seen when the same drug dose was injected under quiet resting conditions (Fig. $4 F ; 41.3 \pm 0.6^{\circ} \mathrm{C}$ vs $\left.37.2 \pm 0.4^{\circ} \mathrm{C} ; t_{(16)}=5.9, p<0.01\right)$. The increase in NAc-Muscle differential $\left(F_{(5,593)}=15.0, p<0.001\right)$ was also significantly larger (Fig. $4 B, E$ ), doubling the values seen under quiet resting conditions (Fig. $4 G ; 0.45 \pm 0.02^{\circ} \mathrm{C}$ vs $0.23 \pm 0.01^{\circ} \mathrm{C}$ in control; $\left.t_{(16)}=9.8, p<0.01\right)$. In each individual rat, this parameter further increased, peaking within \pm 2 min of termination of breathing, and rapidly falling to negative values thereafter (Fig. 5A,B). While Brain-Muscle temperature differentials are always positive (i.e., brain is warmer than temporal muscle) under normal physiological conditions (Kiyatkin, 2010), they rapidly become negative within minutes after death when the brain becomes colder than the body (Fig. 5C). This change is fundamental to brain death, showing rapid and irreversible termination of brain metabolism (Kiyatkin et al., 2007). MDMA injected at warm temperature also robustly decreased Skin-Muscle temperature differentials $\left(-2.5^{\circ} \mathrm{C} ; F_{(5,593)}=13.0, p<0.001\right)$, suggesting 
A

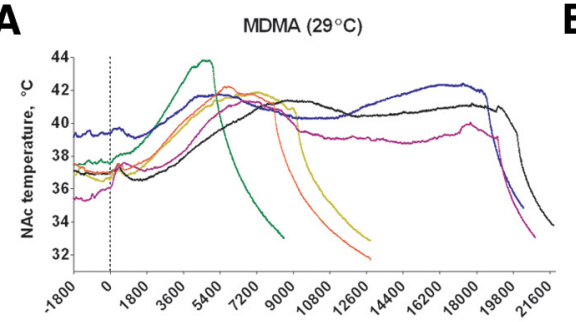

B

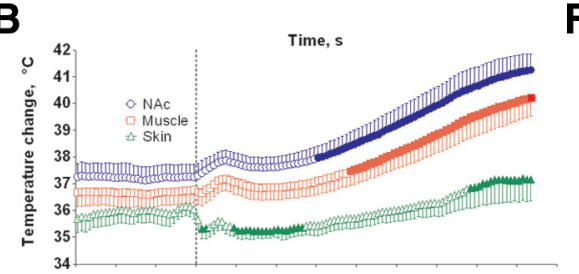

C

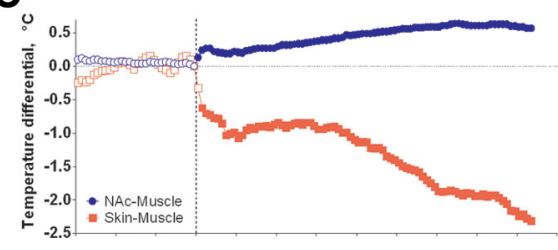

D

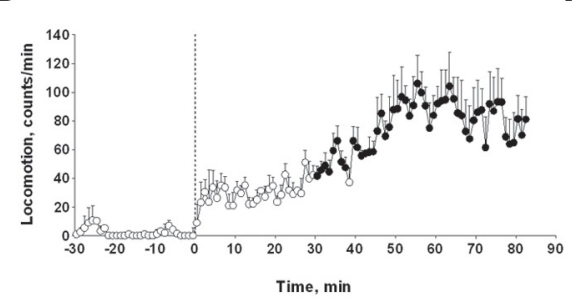

E

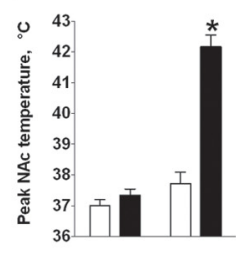

$\mathbf{F}$

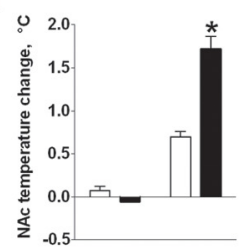

G

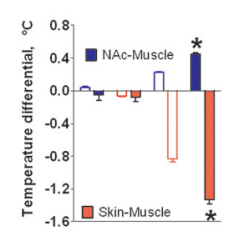

H

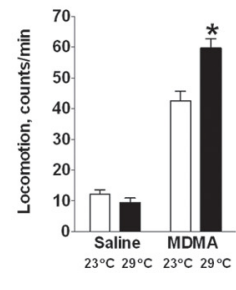

Figure 4. Fatal potentiation of MDMA-induced brain hyperthermia at warm ambient temperatures (I). $A$, Individual changes in brain temperatures following MDMA injections $(9 \mathrm{mg} / \mathrm{kg}$ ) at $29^{\circ} \mathrm{C}$. Mean ( \pm SEM) MDMA-induced changes in NAC, muscle, and skin temperatures $(\boldsymbol{B})$; NAc-Muscle and Skin-Muscle temperature differentials ( $\boldsymbol{C}$; and locomotion (D) at $29^{\circ} \mathrm{C}$ ambient temperature. Filled symbols show values significantly different from baseline. $\boldsymbol{F}-\boldsymbol{H}$, Differences in MDMA effects at standard $\left(22-23^{\circ} \mathrm{C}\right.$; white bar $)$ and warm $\left(29^{\circ} \mathrm{C}\right.$; black bar $)$ ambient temperatures. Asterisks show significant between-group differences $\left({ }^{*} p<0.05\right)$. For comparison, we also show changes in the same parameters induced by saline injection at $23^{\circ} \mathrm{C}$ and $29^{\circ} \mathrm{C}$.

strong and sustained skin vasoconstriction, which greatly exceeded the same effect occurring during quiet resting conditions (Fig. 4G). In contrast to the rapid, terminal drop in NAc-Muscle differentials, Skin-Muscle differentials remained strongly negative until the rat stopped breathing and slowly increased thereafter (Fig. 5C). MDMA at $29^{\circ} \mathrm{C}$ also induced significantly higher locomotor activity than under normal room temperature conditions, but the rats stopped gross motor activity $30-40 \mathrm{~min}$ before death.

\section{Discussion}

Our results demonstrate a dramatic enhancement of MDMAinduced brain hyperthermia during social interaction and in warm environments. Importantly, we found that robust impairment of heat loss due to sustained peripheral vasoconstriction appears to be the primary mechanism underlying the activityand state-dependent potentiation of MDMA-induced brain hyperthermia. Because of this persistent vasoconstriction, MDMA at a moderate, nontoxic dose becomes highly toxic, causing fatal hyperthermia under environmental conditions commonly encountered in humans.

A

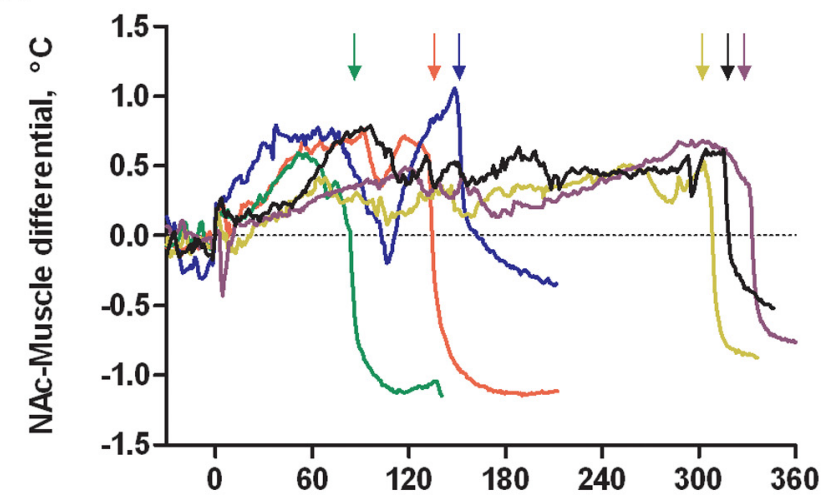

B

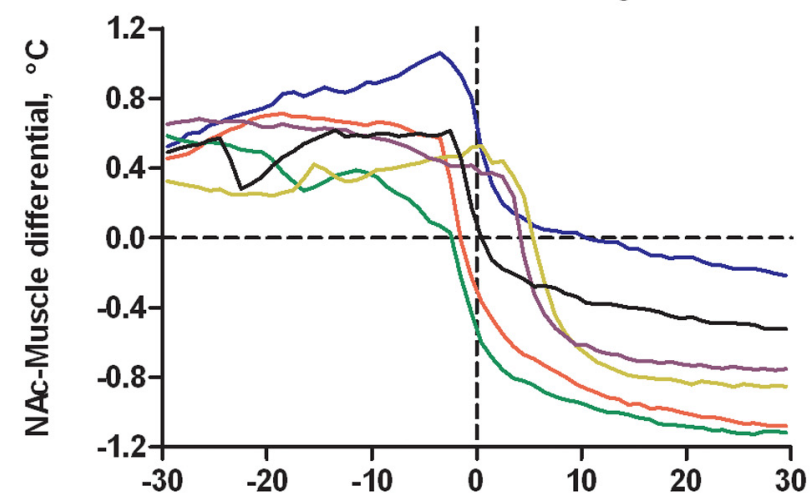

C

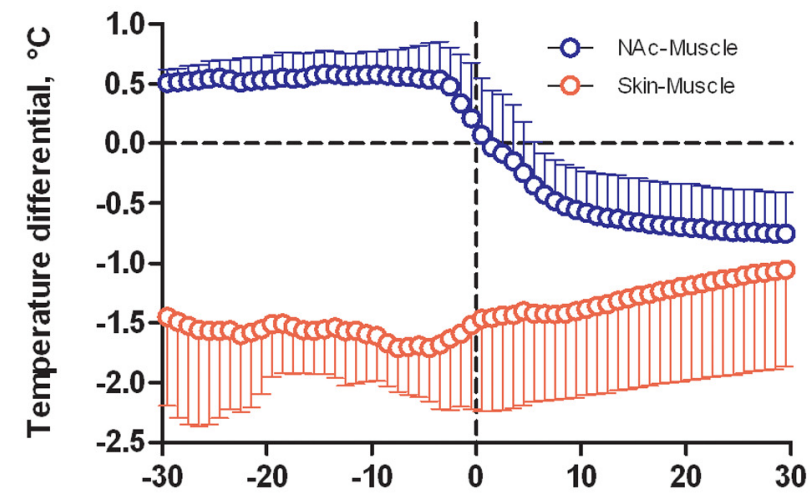

Time, min

Figure 5. Fatal potentiation of MDMA-induced brain hyperthermia at warm ambient temperatures (II). $A$, NAc-Muscle temperature differentials induced by MDMA administered at $29^{\circ} \mathrm{C}$ in individual rats. Arrows of respective colors show the moment of termination of breathing. $\boldsymbol{B}$, Individual changes in NAc-Muscle differentials preceding and following termination of breathing $(0 \mathrm{~min}) . C$, Mean ( \pm SEM) changes in NAc-Muscle and Skin-Muscle differentials preceding and following termination of breathing. Both parameters were determined with respect to pre-injection baseline but shown with respect to the time of death.

\section{Effects of MDMA under standard laboratory conditions}

Consistent with previous reports (Gordon et al., 1991; Mechan et al., 2002; Brown et al., 2003), the temperature effects of MDMA were dose dependent and highly variable for a given drug dose (Fig. 1). Unlike methamphetamine, a widely abused stimulant drug (Hanson et al., 2004) that also induces dose-dependent motor activation and brain hyperthermia (Brown et al., 2003), the low and middle MDMA doses we used (1 and $3 \mathrm{mg} / \mathrm{kg}$ ) had 
virtually no detectable effects on these measures. However, the Skin-Muscle differential showed a clear biphasic fluctuation at 1 $\mathrm{mg} / \mathrm{kg}$ and a larger, more prolonged decrease at $3 \mathrm{mg} / \mathrm{kg}$, indicating peripheral vasoconstriction. Peripheral vasoconstriction was greatly amplified by MDMA at $9 \mathrm{mg} / \mathrm{kg}$, a dose that induced hyperthermia in both the NAc and muscle $\left(\sim 2^{\circ} \mathrm{C}\right)$, and locomotor activation.

The temperature increases induced by MDMA under normal resting conditions were lower or similar in magnitude to those seen during exposure to various arousing stimuli (Kiyatkin, 2010), including social interaction (Fig. 2). However, these changes were prolonged, greatly exceeding the reported half-life of the drug in plasma (Baumann et al., 2009; Concheiro et al., 2014). As shown previously, long-lived metabolites of MDMA, particularly 3,4-methylenedioxyamphetamine, are likely responsible for these sustained temperature increases (Concheiro et al., 2014). At the $9 \mathrm{mg} / \mathrm{kg}$ dose, MDMA-induced peripheral vasoconstriction was also greater and more prolonged than that seen with natural arousing stimuli or methamphetamine in our previous study (Brown et al., 2003). Similar to methamphetamine and social interaction, MDMA ( $9 \mathrm{mg} / \mathrm{kg}$ ) increased NAc-Muscle temperature differentials. While this effect was modest, its duration $(\sim 3 \mathrm{~h})$ greatly exceeded that seen under any physiological conditions.

\section{Potentiation of MDMA effects by social interaction and warm environment}

Brain temperature increases induced by natural arousing stimuli depend on two principal factors: an increase in intrabrain heat production due to metabolic neural activation, and heat retention due to peripheral vasoconstriction (Kiyatkin, 2010). Both of these effects are normally transient; vasoconstriction rapidly rebounds into vasodilation, and brain temperature returns to basal levels due to enhanced heat dissipation to the external environment. However, when MDMA was administered during social interaction, which by itself induces metabolic brain activation and transient vasoconstriction, its hyperthermic and vasoconstrictive effects were greatly amplified.

Even stronger potentiation of MDMA hyperthermic and vasoconstrictive effects occurred in a moderately warm environment (within the rat thermo-neutral zone; Romanovsky et al., 2002), when cutaneous vessels were already dilated and skin temperature was increased to enhance heat dissipation from the body. Under these conditions, MDMA caused lethal hyperthermia within the first $6 \mathrm{~h}$ post injection in all rats. In this case, MDMA also induced greater locomotor activation and pathological increases in NAc-Muscle differentials, suggesting progressive heat accumulation in brain tissue. While NAc-Muscle differentials in each individual case reached their peak immediately preceding termination of breathing and rapidly fell thereafter, Skin-Muscle differentials were tonically inhibited until termination of breathing and then slowly increased toward baseline due to the loss of circulation and slow heat dissipation to the external environment (Fig. 5). In fact, the $100 \%$ mortality rate for $9 \mathrm{mg} / \mathrm{kg}$ MDMA was surprising, because the reported $\mathrm{LD}_{50}$ of MDMA in rats is $49 \mathrm{mg} / \mathrm{kg}$ (Davis et al., 1987). Although peripheral vasoconstriction is a known effect of MDMA (Lester et al., 2000; Pedersen and Blessing, 2001), our current findings clearly identify its critical importance in mediating brain hyperthermia induced by MDMA under certain environmental conditions. Therefore, by increasing intracerebral heat production and strongly inhibiting heat loss due to sustained cutaneous vasoconstriction, MDMA in a moderate "nontoxic" dose becomes highly toxic, inducing pathological hyperthermia leading to lethality under conditions when heat production is naturally increased and/or heat loss is diminished.

\section{Translational relevance}

The MDMA doses in our study approximate the wide range of recreational use in humans. While some proponents recommend MDMA at 1.5-1.7 mg/kg for treatment of PTSD (Doblin, 2002; Vollenweider et al., 2002), recreational users generally consume $\sim 1.0-3.0 \mathrm{mg} / \mathrm{kg}$ (Baylen and Rosenberg, 2006; Dumont and Verkes, 2006; Parrott, 2013). It is not unusual, however, for experienced MDMA users to take higher doses in an attempt to overcome tolerance to the drug's subjective effects (Parrott, 2013). Similar to the slow development of hyperthermia in rats, the desired psychoactive effects of oral MDMA in human users develop with relatively long latencies that could lead to multiple drug dosing.

The $9 \mathrm{mg} / \mathrm{kg}$ dose in the present study is higher than the typical human dose, but it is only $1 / 5$ of the $\mathrm{LD}_{50}$ in rats (Davis et al., 1987) and does not cause neurotoxicity or any evident health complications in rats under standard laboratory conditions (Green et al., 2003; Baumann et al., 2007). When rats received 10 $\mathrm{mg} / \mathrm{kg}$ of MDMA, its circulating levels ranged from 0.8 to $1 \mathrm{mg} / \mathrm{L}$ (Baumann and Rothman, 2009; Concheiro et al., 2014), within the range found in rave party participants who self-administer recreational doses of the drug (Irvine et al., 2006). However, much higher blood levels of MDMA ( $~ 8.5 \mathrm{mg} / \mathrm{L})$, suggesting higher doses of drug intake, were found in humans that had died from an MDMA overdose (Milroy, 2011). Additionally, when interspecies scaling methods are used to adjust for species differences in body mass and metabolism (Mordenti and Chappell, 1989), $9 \mathrm{mg} / \mathrm{kg}$ in rats falls within the dose range used by humans recreationally. While dose is a major factor in drug-induced toxicity, the same MDMA dose may also induce different changes in drug levels in plasma and brain, because of individual differences in MDMA metabolism (Ramamoorthy et al., 2002; Green et al., 2003), which is nonlinear in both rats and humans (de la Torre et al., 2000; Baumann et al., 2009; Concheiro et al., 2014) and is inhibited at higher temperatures (Green et al., 2003).

Rats and humans differ in their thermo-effector mechanisms (Gordon, 2007), questioning the applicability of our findings to human conditions. While rats are less sensitive than humans to environmental cooling, humans have more efficient mechanisms of heat dissipation than other species, because of humans' ability to sweat (perspiration) and a very high dynamic range of blood flow rates in the skin (Rowell, 1983). However, warm and humid environments significantly diminish these adaptive mechanisms of heat loss, while psychophysiological activation enhances brain and body heat production. When these factors are combined with MDMA, which by itself induces intracerebral heat production coupled with a strong and prolonged cutaneous vasoconstriction, heat is progressively accumulated in the brain and body, resulting in pathological hyperthermia and lethality.

Although hyperthermia is commonly viewed as the most dangerous symptom of acute MDMA-induced intoxication, it is also a likely cause of other potentially fatal complications, including rhabdomyolysis, disseminated intravenous coagulation, hemodilution, and hyponatremia (Kalant, 2001). By increasing the permeability of the blood-brain barrier, MDMA induces progressive water accumulation in brain tissue, leading to brain edema (Sharma and Ali, 2008). As shown with methamphetamine (Kiyatkin et al., 2007) and confirmed with passive body warming (Kiyatkin and Sharma, 2009), brain hyperthermia by 
itself is a leading factor for the leakage of the blood-brain barrier and the development of vasogenic edema, which appears to be the final cause for lethality. MDMA also promotes water retention in the body via the release of antidiuretic hormone (Satchell and Connaughton, 1994), further impairing the organism's ability to lose heat by evaporation or water expulsion, and potentiating drug-induced brain edema. Importantly, these effects could be exacerbated by the excessive intake of liquids, which often accompanies MDMA use during rave parties. High brain temperatures could also irreversibly damage mitochondria and induce cell death (Iwagami, 1996; Lepock, 2003). Thus, MDMA-induced brain hyperthermia is also a significant factor causing structural abnormalities of brain cells (Sharma and Kiyatkin, 2009) and potentiating neurotoxicity-another dangerous complication of chronic MDMA use in humans (McCann et al., 1996; Ricaurte et al., 2000; Ricaurte and McCann, 2001).

\section{Conclusions}

In contrast to the popular belief that "recreational" use of MDMA is safe, our data demonstrate that exposure to MDMA combined with a specific combination of individual and environmental factors can in fact be deadly. Our study identifies peripheral vasoconstriction as a critical mechanism responsible for the strong activity- and state-dependent potentiation of MDMA-induced brain hyperthermia. These data further suggest that medical interventions aimed at increasing the efficiency of whole-body cooling by targeting cutaneous vasoconstriction could be therapeutically relevant for counteracting the development of MDMA-induced pathological hyperthermia. The high individual variability, long duration of MDMA actions, and strong modulation of the drug's effect by environmental factors suggest that the dangers of MDMA in humans may be underestimated.

\section{References}

Badiani A, Belin D, Epstein D, Calu D, Shaham Y (2011) Opiate versus psychostimulant addiction: the differences do matter. Nat Rev Neurosci 12:685-700. CrossRef Medline

Baumann MH, Rothman RB (2009) Neural and cardiac toxicities associated with 3,4-methylenedioxymethamphetamine (MDMA). Int Rev Neurobiol 88:257-296. CrossRef Medline

Baumann MH, Wang X, Rothman RB (2007) 3,4-Methylenedioxymethamphetamine (MDMA) neurotoxicity in rats: a reappraisal of past and present findings. Psychopharmacology 189:407-424. Medline

Baumann MH, Zolkowska D, Kim I, Scheidweiler KB, Rothman RB, Huestis MA (2009) Effects of dose and route of administration on pharmacokinetics of $(+$ or -$)-3,4$-methylenedioxymethamphetamine in the rat. Drug Metab Dispos 37:2163-2170. CrossRef Medline

Baylen CA, Rosenberg H (2006) A review of the acute subjective effects of MDMA/ecstasy. Addiction 101:933-947. CrossRef Medline

Blessing WW, Seaman B, Pedersen NP, Ootsuka Y (2003) Clozapine reverses hyperthermia and sympathetically mediated cutaneous vasconstriction induced by 3,4-methylenedioxymethamphetamine (ecstasy) in rabbits and rats. J Neurosci 23:6385-6391. Medline

Bouso JC, Doblin R, Farré M, Alcázar MA, Gómez-Jarabo G (2008) MDMA-assisted psychotherapy using low doses in a small sample of women with chronic posttraumatic stress disorder. J Psychoactive Drugs 40:225-236. CrossRef Medline

Brown PL, Kiyatkin EA (2004) Brain hyperthermia induced by MDMA (ecstasy): modulation by environmental conditions. Eur J Neurosci 20:5158. CrossRef Medline

Brown PL, Wise RA, Kiyatkin EA (2003) Brain hyperthermia is induced by methamphetamine and exacerbated by social interaction. J Neurosci 23: 3924-3929. Medline

Carvalho M, Carvalho F, Remião F, de Lourdes Pereira M, Pires-das-Neves R, de Lourdes Bastos M (2002) Effect of 3,4-methylenedioxymethamphetamine ("ecstasy") on body temperature and liver antioxidant status in mice: influence of ambient temperature. Arch Toxicol 76:166-172. CrossRef Medline
Check E (2004) Psychedelic drugs: the ups and downs of ecstasy. Nature 429:126-128. CrossRef Medline

Concheiro M, Baumann MH, Scheidweiler KB, Rothman RB, Marrone GF, Huestis MA (2014) Nonlinear pharmacokinetics of $(\{+/-\}) 3,4-$ methylenedioxymethamphetamine (MDMA) and its pharmacodynamic consequences in the rat. Drug Metab Dispos 42:119-125. CrossRef Medline

Davis WM, Hatoum HT, Waters IW (1987) Toxicity of MDA (3,4methylenedioxyamphetamine) considered for relevance to hazards of MDMA (ecstasy) abuse. Alcohol Drug Res 7:123-134. Medline

de la Torre R, Farré M, Ortuño J, Mas M, Brenneisen R, Roset PN, Segura J, Camí J (2000) Non-linear pharmacokinetics of MDMA ('ecstasy') in humans. Br J Clin Pharmacol 49:104-109. Medline

Doblin R (2002) A clinical plan for MDMA (ecstasy) in the treatment of posttraumatic stress disorder (PTSD): partnering with the FDA. J Psychoactive Drugs 34:185-194. CrossRef Medline

Dumont GJ, Verkes RJ (2006) A review of acute effects of 3,4methylenedioxymethamphetamine in healthy volunteers. J Psychopharmacol 20:176-187. CrossRef Medline

Fantegrossi WE, Godlewski T, Karabenick RL, Stephens JM, Ullrich T, Rice KC, Woods JH (2003) Pharmacological characterization of the effects of 3,4-methylenedioxymethamphetamine ("ecstasy") and its enantiomers on lethality, core temperature, and locomotor activity in singly housed and crowded mice. Psychopharmacology 166:202-211. Medline

Freedman RR, Johanson CE, Tancer ME (2005) Thermoregulatory effects of 3,4-methylenedioxymethamphetamine (MDMA) in humans. Psychopharmacology 183:248-256. CrossRef Medline

Gordon CJ (2007) Thermophysiological responses to hyperthermic drugs: extrapolating from rodent to human. Prog Brain Res 162:63-79. CrossRef Medline

Gordon CJ, Watkinson WP, O'Callaghan JP, Miller DB (1991) Effects of 3,4-methylenedioxymethamphetamine on autonomic thermoregulatory responses of the rat. Pharmacol Biochem Behav 38:339-344. CrossRef Medline

Green AR, Mechan AO, ElliottJM, O'Shea E, Colado MI (2003) The pharmacology and clinical pharmacology of 3,4-methylenedioxymethamphetamine (MDMA, "ecstasy"). Pharmacol Rev 55:463-508. CrossRef Medline

Hanson GR, Rau KS, Fleckenstein AE (2004) The methamphetamine experience: a NIDA partnership. Neuropharmacology 47 [Suppl 1]:92-100. Medline

Irvine RJ, Keane M, Felgate P, McCann UD, Callaghan PD, White JM (2006) Plasma drug concentrations and physiological measures in 'dance party' participants. Neuropsychopharmacology 31:424-430. CrossRef Medline

Iwagami Y (1996) Changes in the ultrastructure of human cells related to certain biological responses under hyperthermic culture conditions. Hum Cell 9:353-366. Medline

Kalant H (2001) The pharmacology and toxicology of "ecstasy" (MDMA) and related drugs. CMAJ 165:917-928. Medline

Kiyatkin EA (2010) Brain temperature homeostasis: physiological fluctuations and pathological shifts. Front Biosci 15:73-92. CrossRef Medline

Kiyatkin EA (2013) The hidden side of drug action: brain temperature changes induced by neuroactive drugs. Psychopharmacology 225:765780. CrossRef Medline

Kiyatkin EA, Brown PL (2004) Modulation of physiological brain hyperthermia by environmental temperature and impaired blood outflow in rats. Physiol Behav 83:467-474. CrossRef Medline

Kiyatkin EA, Brown PL (2005) Brain and body temperature homeostasis during sodium pentobarbital anesthesia with and without body warming in rats. Physiol Behav 84:563-570. CrossRef Medline

Kiyatkin EA, Sharma HS (2009) Permeability of the blood-brain barrier depends on brain temperature. Neuroscience 161:926-939. CrossRef Medline

Kiyatkin EA, Brown PL, Sharma HS (2007) Brain edema and breakdown of the blood-brain barrier during methamphetamine intoxication: critical role of brain hyperthermia. Eur J Neurosci 26:1242-1253. CrossRef Medline

Kolbrich EA, Goodwin RS, Gorelick DA, Hayes RJ, Stein EA, Huestis MA (2008) Plasma pharmacokinetics of 3,4-methylenedioxymethamphetamine after controlled oral administration to young adults. Ther Drug Monit 30:320332. CrossRef Medline

Lepock JR (2003) Cellular effects of hyperthermia: relevance to the minimum dose for thermal damage. Int J Hyperthermia 19:252-266. CrossRef Medline 
Lester SJ, Baggott M, Welm S, Schiller NB, Jones RT, Foster E, Mendelson J (2000) Cardiovascular effects of 3,4-methylenedioxymethamphetamine. A double-blind, placebo-controlled trial. Ann Intern Med 133:969-973. CrossRef Medline

McCann UD, Slate SO, Ricaurte GA (1996) Adverse reactions with 3,4methylenedioxymethamphetamine (MDMA; 'ecstasy'). Drug Saf 15:107115. CrossRef Medline

Mechan AO, Esteban B, O'Shea E, Elliott JM, Colado MI, Green AR (2002) The pharmacology of the acute hyperthermic response that follows administration of 3,4-methylenedioxymethamphetamine (MDMA, 'ecstasy') to rats. Br J Pharmacol 135:170-180. CrossRef Medline

Miller DB, O'Callaghan JP (2003) Elevated environmental temperature and methamphetamine neurotoxicity. Environ Res 92:48-53. CrossRef Medline

Milroy CM (2011) "Ecstasy" associated deaths: what is a fatal concentration? Analysis of a case series. Forensic Sci Med Pathol 7:248-252. CrossRef Medline

Mithoefer MC, Wagner MT, Mithoefer AT, Jerome L, Martin SF, Yazar-Klosinski B, Michel Y, Brewerton TD, Doblin R (2013) Durability of improvement in post-traumatic stress disorder symptoms and absence of harmful effects or drug dependency after 3,4-methylenedioxymethamphetamine-assisted psychotherapy: a prospective long-term follow-up study. J Psychopharmacol 27:28-39. CrossRef Medline

Mogenson GJ, Jones DL, Yim CY (1980) From motivation to action: functional interface between the limbic system and the motor system. Prog Neurobiol 14:69-97. CrossRef Medline

Mordenti J, Chappell W (1989) The use of interspecies scaling in toxicokinetics. In: Toxicokinetics and new drug development (Yacobi A, Kelly J, Batra V, eds), pp 42-96. New York: Pergamon.

Parrott AC (2013) Human psychobiology of MDMA or 'ecstasy': an overview of 25 years of empirical research. Hum Psychopharmacol 28:289307. CrossRef Medline

Paxinos G, Watson C (2005) The rat brain in stereotaxic coordinates, 5 Edition. Amsterdam: Elsevier Academic.

Pedersen NP, Blessing WW (2001) Cutaneous vasoconstriction contributes to hyperthermia induced by 3,4-methylenedioxymethamphetamine (ecstasy) in conscious rabbits. J Neurosci 21:8648-8654. Medline

Pentney AR (2001) An exploration of the history and controversies surrounding MDMA and MDA. J Psychoactive Drugs 33:213-221. CrossRef Medline

Ramamoorthy Y, Yu AM, Suh N, Haining RL, Tyndale RF, Sellers EM (2002)
Reduced (+/-)-3,4-methylenedioxymethamphetamine ("ecstasy") metabolism with cytochrome P450 2D6 inhibitors and pharmacogenetic variants in vitro. Biochem Pharmacol 63:2111-2119. CrossRef Medline

Ricaurte GA, McCann UD (2001) Experimental studies on 3,4methylenedioxymethamphetamine (MDA, "ecstasy") and its potential to damage brain serotonin neurons. Neurotox Res 3:85-99. CrossRef Medline

Ricaurte GA, Yuan J, McCann UD (2000) (+/-)3,4-Methylenedioxymethamphetamine ('ecstasy')-induced serotonin neurotoxicity: studies in animals. Neuropsychobiology 42:5-10. CrossRef Medline

Romanovsky AA, Ivanov AI, Shimansky YP (2002) Selected contribution: ambient temperature for experiments in rats: a new method for determining the zone of thermal neutrality. J Appl Physiol (1985) 92:2667-2679.

Rowell LB (1983) Cardiovascular aspects of human thermoregulation. Circ Res 52:367-379. CrossRef Medline

Rusyniak DE, Ootsuka Y, Blessing WW (2008) When administered to rats in a cold environment, 3,4-methylenedioxymethamphetamine reduces brown adipose tissue thermogenesis and increases tail blood flow: effects of pretreatment with 5-HT1A and dopamine D2 antagonists. Neuroscience 154:1619-1626. CrossRef Medline

Satchell SC, Connaughton M (1994) Inappropriate antidiuretic hormone secretion and extreme rises in serum creatinine kinase following MDMA ingestion. Br J Hosp Med 51:495. Medline

Sharma HS, Ali SF (2008) Acute administration of 3,4-methylenedioxymethamphetamine induces profound hyperthermia, blood-brain barrier disruption, brain edema formation, and cell injury. Ann N Y Acad Sci 1139:242-258. CrossRef Medline

Sharma HS, Kiyatkin EA (2009) Rapid morphological brain abnormalities during acute methamphetamine intoxication in the rat: an experimental study using light and electron microscopy. J Chem Neuroanat 37:18-32. CrossRef Medline

Smirnov MS, Kiyatkin EA (2008) Fluctuations in central and peripheral temperatures associated with feeding behavior in rats. Am J Physiol Regul Integr Comp Physiol 295:R1415-R1424. CrossRef Medline

United Nations World Drug Report (2013) New York: United Nations.

Vollenweider FX, Liechti ME, Gamma A, Greer G, Geyer M (2002) Acute psychological and neurophysiological effects of MDMA in humans. J Psychoactive Drugs 34:171-184. CrossRef Medline

Wise RA (1989) The brain and reward. In: The neuropharmacological basis of reward (Liebman JM, Kooper SJ, eds), pp 377-424. Oxford: Oxford UP. 